\title{
PEMANFAATAN BUAH SIRSAK (ANNONA MURICATA) UNTUK PEMBUATAN PUREE MENJADI PRODUK SIAP PAKAI DAN PEMASARANNYA
}

\section{THE USAGE OF SOURSOP FRUIT (ANNONA MURICATA) FOR MAKING PUREE INTO READY TO USE PRODUCT AND ITS MARKETING}

\author{
Prajna Bala Wiradharma
}

\author{
Sekolah Tinggi Pariwisata Trisakti \\ Jl. IKPN Bintaro No.1 Pesanggrahan Tanah Kusir, Jakarta Selatan, 12330
}

\begin{abstract}
ABSTRAK
Penelitian ini bertujuan untuk mengetahui proses pembuatan, kemasan dan teknik pemasaran puree sirsak. Metode penelitian yang digunakan adalah metode eksperimental kuantitatif. Buah sirsak yang digunakan berasal dari Garut, Jawa Barat. Hasil uji hedonik, sebanyak 50\% responden agak suka terhadap rasa puree, $43,3 \%$ responden sangat suka terhadap aroma puree dan $43,3 \%$ responden agak suka terhadap tekstur puree. Hasil uji organoleptik, sebanyak 43,3\% responden menyatakan rasa cukup asam, $40 \%$ responden menyatakan cukup beraroma sirsak dan $66,7 \%$ responden menyatakan tekstur cukup halus. Sebanyak 53,3\% responden menyatakan kemasan kotak sangat sesuai, karena apabila dalam keadaan beku sangat mudah untuk dikeluarkan. Logo berbentuk lonjong terinspirasi dari bentuk buah sirsak. Analisis pemasaran STP : Puree sirsak dikemas dalam ukuran 1 liter, karena konsumen yang dituju adalah pastry shop yang produksi dalam kapasitas cukup banyak. Harga jual berkisar Rp. 77.000 berada di bawah harga puree yang ada dipasaran Analisis pemasaran metode Mix 4P : Puree sirsak baik untuk kesehatan, dapat juga dibuat menjadi pastry product, dijual seharga Rp, 77.000,- untuk setiap 1 liter sesuai dengan daya beli pelanggan dan harga kompetitor yang ada di pasaran.
\end{abstract}

Kata kunci : sirsak, puree, siap pakai, pemasaran

\section{ABSTRACT}

This study aims to determine the manufacturing process, packaging and marketing techniques of soursop puree. The research method used is quantitative experimental method. The soursop fruit used comes from Garut, West Java. The results of the hedonic test, as many as 50\% of respondents liked the taste of puree somewhat, $43.3 \%$ of respondents really liked the aroma of puree and $43.3 \%$ of respondents liked the texture of the puree somewhat. The results of the organoleptic test, $43.3 \%$ of respondents stated that the taste was quite sour, $40 \%$ of the respondents stated that it had quite the aroma of soursop and $66.7 \%$ of respondents said the texture was quite smooth. As many as $53.3 \%$ of respondents stated that the box packaging is very suitable, because when it is frozen it is very easy to remove. The oval-shaped logo is inspired by the shape of the soursop fruit. STP marketing analysis: Soursop puree is packaged in 1 liter size, because the intended consumer is a pastry shop with a large capacity. Marketing analysis of the Mix $4 P$ method: Soursop puree is good for health, can also be made into a pastry product, selling for IDR 77,000 for every 1 liter according to customer purchasing power and competitive prices on the market.

Keywords: soursop; puree; ready to use; marketing

\section{Pendahuluan}

Sirsak (Annona muricata L) merupakan salah satu tanaman buah yang berasal dari

\footnotetext{
${ }^{*}$ Penulis Korespondensi.

E-mail: prajna@stptrisakti.ac.id

Telp: +62-81282956406
}

Karibia, Amerika Tengah dan Amerika Selatan. Buah sirsak rasanya manis agak asam sehingga sering dipakai sebagai bahan jus buah. Daging buahnya kaya akan serat. (Teyler, 2002). Daging buah sirsak yang matang dapat dimakan segar atau dibuat jus. Saat ini, sebagian besar sirsak dikonsumsi dalam bentuk minuman olahan. 
Produk olahan sirsak lainnya berupa jelly, permen atau dodol. (Ashari, 2006).

Buah sirsak terdiri atas $67,5 \%$ daging buah yang dapat dimakan, $20 \%$ kulit, 8,5\% biji, dan 4 $\%$ empulur. Biji pada tanaman sirsak bersifat racun dan dapat dimanfaatkan sebagai insektisida alami, sedangkan daun sirsak dapat bermanfaat dalam menghambat pertumbuhan sel kanker dengan menginduksi apoptosis, analgetik, anti disentri, anti asma, antihelmitic, dilatasi pembuluh darah, menstimulasi pencernaan, dan mengurangi depresi. Batang dan daun memiliki kandungan zat annonaceous acetogenins yang menunjukkan sitotoksik aktif melawan sel kanker, selain mengandung zat annonaceous acetogein, terdapat kandungan flavonoid, Tanin, dan saponin pada ekstrak air daun sirsak, yang berfungsi dalam menghambat pertumbuhan tumor. Selain sifat anti kanker, sirsak juga memiliki sifat anti bakteri, anti jamur, dan efektif dalam melawan berbagai jenis parasit atau cacing, bahkan sirsak dapat mengobati tekanan darah tinggi, depresi, dan stres (Komansilan, dkk., 2012).

Sirsak diperkaya dengan vitamin, mineral, dan serat pangan. Mengonsumsi $100 \mathrm{~g}$ daging sirsak dapat mencukupi kebutuhan serat harian sebesar 13\%. Dalam $100 \mathrm{~g}$ daging sirsak mengandung sekitar $20 \mathrm{mg}$ Vitamin C. Vitamin $\mathrm{C}$ dapat membantu menjaga daya tahan tubuh, menghindari diri dari radikal bebas, dan menghindari penuaan dini. Selain itu, buah sirsak banyak mengandung zat mineral penting seperti fosfor sekitar $27 \mathrm{mg}$ dan kalsium $14 \mathrm{mg}$ per 100 g pada buahnya. Kedua kandungan ini adalah nutrisi yang penting untuk kesehatan tulang.(Maria, 2013). Nilai gizi buah sirsak dapat dilihat pada Tabel 1 dibawah ini.

Tabel 1. Kandungan Zat Gizi Buah Sirsak/100gr

\begin{tabular}{lccc}
\hline Kandungan & Jumlah & Kandungan & Jumlah \\
\hline Energi & $65,0 \mathrm{kal}$ & Besi & $0,60 \mathrm{mg}$ \\
Protein & $1,0 \mathrm{~g}$ & Vitamin A & $1,0 \mathrm{RE}$ \\
Lemak & $0,30 \mathrm{~g}$ & Vitamin B1 & 0,07 \\
& & & $\mathrm{mg}$ \\
Karbohidrat & $16,30 \mathrm{~g}$ & Vitamn B2 & 0,04 \\
& & & $\mathrm{mg}$ \\
Kalsium & $14,0 \mathrm{mg}$ & Vitamin C & 20,0 \\
& & & $\mathrm{mg}$ \\
Fosfor & $27,00 \mathrm{mg}$ & Niacin & 0,70 \\
Serat & $2,00 \mathrm{~g}$ & & $\mathrm{mg}$ \\
\hline
\end{tabular}

Sumber : Mardiana \& Ratnasari (2011)
Menurut (Setyadjit et al., 2005) Puree adalah produk antara yang dapat diolah lebih lanjut menjadi aneka produk makanan dan minuman seperti jus, jelly, dodol dan es krim. Sedangkan menurut (Broto, 2003) adalah bahan setengah jadi yang digunakan sebagai bahan baku pembuatan minuman sari buah atau netar, produk roti dan susu, permen, selai, dan jeli.

Penelitian sebelumnya tentang puree sirsak dilakukan penyimpanaan selama 12 minggu, dan diketahui puree yang disimpan dalam keadaan beku pada suhu $-20^{\circ} \mathrm{C}$ serta $4^{0} \mathrm{C}$ tidak menunjukkan adanya penurunan kandungan nutrisi yang signifikan dan berdasarkan analisa sensorik Puree sirsak tersebut masih dapat diterima dan tidak terjadi perubahan warna yang nyata, akan tetapi apabila disimpan pada suhu $15^{\circ} \mathrm{C}$ puree sirsak hanya dapat bertahan selama 6 minggu (Umme et al., 1997).

Penyimpanan dingin puree membutuhkan kemasan. Kemasan menurut Wijayanti (2012) adalah upaya yang dilakukan oleh perusahaan umtuk memberikan informasi kepada setiap konsumennya tentang produk yang ada di dalamnya. Kemasan yang baik menurut Widya (2017) adalah sebagai berikut : (1) Memiliki nilai efektivitas (2) Menjamin keamanan produk (3) Memudahkan pengiriman (4) Mudah dikenali (5) Menyertakan informasi bahan dan izin terkait (6) Desain ergonomis (7) Memperhatikan faktor keindahan.

Puree yang telah dikemas siap untuk dipasarkan. Sebelum memasarkan produk harus ada analisa pasar agar produk itu dapat diterima di masyarakat. Terdapat 2 analisa pasar yang digunakan yaitu analisa pasar STP (Segmenting, Targeting, Positioning) dan analisa pasar marketing mix.

Analisa pasar STP yaitu : (1) Segmentasi Menurut Tjiptono \& Chandra (2012) adalah sebagai proses mengelompokkan pasar keseluruh yang heterogen menjadi kelompok - kelompok atau segmen - segmen yang memiliki kesamaan dalam hal kebutuhan, keinginan, prilaku atau respon terhadap program pemsaran spesifik. (2) Targeting adalah proses mengevaluasi dan memilih satu atau beberapa segmen pasar yang dinilai paling menarik untuk dilayani dangan program pemasaran spesifik perusahaan (Tjiptono \& Chandra, 2012). Menurut Daryanto (2011) targeting adalah proses mengevaluasi daya tarik segmen pasar dan memilih satu atau beberapa untuk dimasuki. (3) Positioning adalah 
cara produk, merek, atau organisasi perusahaan dipersepsikan secara relative dibandingkan dengan produk, merek atau organisasi pesaing oleh pelanggan saat ini maupun calon pelanggan. (Tjiptono \& Chandra, 2012). Menurut Kottler \& Keller (2006) positioning adalah tindakan desain dalam penawaran perusahaan sehingga menempati posisi yang berbeda dan nilai yang ditempatkan dalam benak pelanggan.

Analisa pasar marketing mix atau bauran pemasaran adalah kombinasi dari empat variabel yaitu produk, harga, promosi, dan sistem distribusi (Kotler \& Amstrong 2001), (Kotler \& Amstrong, 2008), Bauran pemasaran (marketing mix) adalah kumpulan alat pemasaran taktis terkendali yang dipadukan perusahaan untuk menghasilkan respons yang diinginkan di pasar sasaran. Kotler \& Amstrong (2008) manyatakan produk adalah semua hal yang dapat ditawarkan kepada pasar untuk menarik perhatian akuisisi, penggunaan atau konsumsi yang dapat memuaskan suatu keinginan atau kebutuhan.

Tujuan penelitian ini adalah menganalisis cara pembuatan puree sirsak, menganalisis kadar kandungan nutrisi pada puree sirsak, menganalisis kemasan yang paling sesuai untuk produk yang terbuat dari puree sirsak dan menganalisis cara memasarkan produk yang terbuat dari puree sirsak dan tempat pemasarannya.

\section{Metode Penelitian}

Metode penelitian yang digunakan penulis dalam penelitian ini berupa metode eksperimental kuantitatif. Bahan yang digunakan dalam pembuatan puree adalah daging buah sirsak 100 gram dan air bersih $100 \mathrm{cc}$. Buah sirsak yang dijadikan puree di beli di Pasar Buah Angke dengan harga Rp. 15.000 per kilogram. Sirsak ini didatangkan dari kota Garut. Proses pembuatan puree sirsak seperti yang terdapat pada Gambar 1.

Uji panelis dilakukan dengan cara menyebar kuesioner untuk menilai produk puree sirsak hasil penelitian. Kuesioner yang akan disebar terbagi menjadi dua jenis yaitu kuesioner uji deskriptif dan kuesioner uji hedonik. Data yang diperoleh dari hasil uji panelis akan ditabulasi menggunakan program Microsoft Excel 2010, lalu akan dihitung dan dianalisa menggunakan program SPSS versi 25.

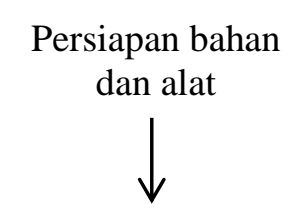

Buah dicuci bersih<smiles>C=[V]</smiles>

Buah dibagi menjadi 2 potong<smiles>C=[14CH]</smiles>

Pemisahan antara daging dan biji<smiles>[TeH]</smiles>

Penimbangan daging buah sirsak
(100 g)
$\downarrow$

Penambahan air dengan perbandingan 1:1 $(100 \mathrm{ml})$<smiles>[Mg][TeH]</smiles>

Pencampuran daging sirsak dengan air<smiles>[Te]</smiles>
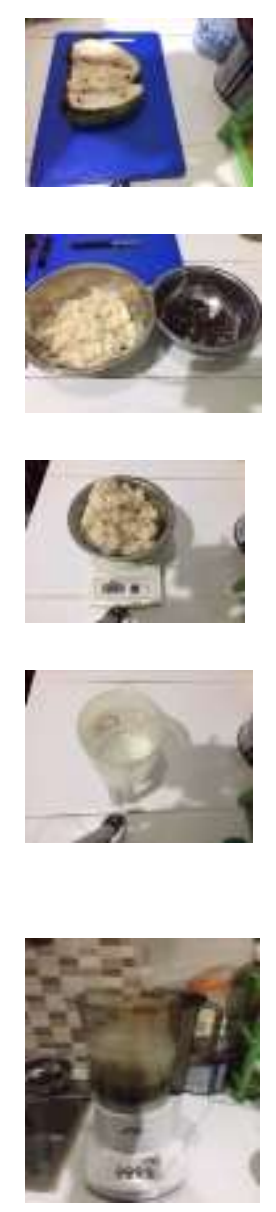

Puree dituang dalam kemasan box<smiles>C=[V]</smiles>

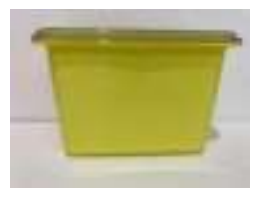

Puree dibekukan dalam freezer

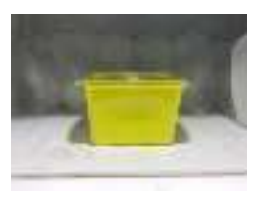

Gambar 1. Proses pembuatan puree sirsak 


\section{Hasil dan Pembahasan}

Panelis yang dipilih untuk uji hedonik dan organoleptik puree sirsak adalah panelis ahli dan panelis tidak terlatih. Pembagian panelis tersebut dapat dilihat pada Tabel 2.

Tabel 2. Identitas responden pada uji panelis

\begin{tabular}{|c|c|c|}
\hline $\begin{array}{c}\text { Keterangan } \\
\text { Jenis Kelamin }\end{array}$ & $\begin{array}{l}\text { Jumlah } \\
\text { (orang) }\end{array}$ & $\begin{array}{c}\text { Persentase } \\
(\%)\end{array}$ \\
\hline Panelis Ahli & & \\
\hline Laki-laki & 5 & $100 \%$ \\
\hline Perempuan & 0 & $0 \%$ \\
\hline Total & 5 & $100 \%$ \\
\hline \multicolumn{3}{|c|}{ Panelis Tidak Terlatih } \\
\hline Laki-laki & 5 & $20 \%$ \\
\hline Perempuan & 20 & $80 \%$ \\
\hline $\begin{array}{c}\text { Total } \\
\text { Usia }\end{array}$ & 25 & $100 \%$ \\
\hline \multicolumn{3}{|l|}{ Panelis Ahli } \\
\hline 33 tahun & 1 & $20 \%$ \\
\hline 40 tahun & 1 & $20 \%$ \\
\hline 42 tahun & 1 & $20 \%$ \\
\hline 43 tahun & 1 & $20 \%$ \\
\hline 46 tahun & 1 & $20 \%$ \\
\hline $\begin{array}{c}\text { Total } \\
\text { Panelis Tidak Terl }\end{array}$ & 5 & $100 \%$ \\
\hline 18 tahun & 17 & $68 \%$ \\
\hline 19 tahun & 8 & $32 \%$ \\
\hline Total & 25 & $100 \%$ \\
\hline
\end{tabular}

Berdasarkan tabel di atas, jenis kelamin panelis ahli $100 \%$ adalah laki - laki, hal ini dikarenakan dosen pastry dan kitchen lebih banyak laki - laki dan jenis kelamin panelis tidak terlatih terbanyak adalah perempuan sebesar 80 $\%$, hal ini menunjukan bahwa mahasiwa perempuan lebih banyak beraktifitas di kampus dibanding mahasiswa laki - laki. Sedangkan usia panelis ahli umurnya bervariatif dan jenis kelamin panelis tidak terlatih terbanyak pada usia 18 tahun sebanyak $68 \%$, karena pada saat penerimaan mahasiswa lebih benyak menerima mahasiswa yang berusia 18 tahun daripada yang berusia 19 tahun.

Parameter uji hedonik terhadap puree sirsak adalah rasa, aroma, dan tekstur dari puree tersebut. Hasil uji hedonik rasa puree sirsak dapat dilihat pada Tabel 3.
Tabel 3. Hasil Uji Hedonik Rasa Puree Sirsak

\begin{tabular}{lcc}
\hline \multicolumn{1}{c}{ Keterangan } & $\begin{array}{c}\text { Jumlah } \\
\text { (orang) }\end{array}$ & $\begin{array}{c}\text { Percent } \\
(\mathbf{\%})\end{array}$ \\
\hline Sangat Tidak Suka & 0 & 0 \\
Tidak Suka & 2 & 6,7 \\
Agak Suka & 15 & 50 \\
Suka & 10 & 33,3 \\
Sangat Suka & 3 & 10 \\
$\quad$ Total & $\mathbf{3 0}$ & $\mathbf{1 0 0}$ \\
\hline
\end{tabular}

Dari tabel dapat dilihat bahwa kesukaan panelis terhadap rasa puree sirsak yang memilih agak suka sebesar 50,0\%. Panelis yang memilih suka sebanyak 33,3\% dan sangat suka sebanyak $10 \%$. Panelis yang memilih tidak suka sebanyak $6,7 \%$. Untuk persentase yang paling besar berada pada skala agak suka karena rasa dari puree sirsak sendiri masih biasa dan belum ditambahkan bahan tambahan lain.

\begin{tabular}{lcc}
\multicolumn{1}{c}{ Tabel 4. Hasil Uji Hedonik Aroma } & Puree Sirsak \\
\hline Keterangan & $\begin{array}{c}\text { Jumlah } \\
\text { (orang) }\end{array}$ & $\begin{array}{c}\text { Percent } \\
(\boldsymbol{\%})\end{array}$ \\
\hline Sangat Tidak Suka & 0 & 0 \\
Tidak Suka & 1 & 3,3 \\
Agak Suka & 10 & 33,3 \\
Suka & 6 & 20 \\
Sangat Suka & 13 & 43,4 \\
\hline \multicolumn{1}{c}{ Total } & $\mathbf{3 0}$ & $\mathbf{1 0 0}$ \\
\hline
\end{tabular}

Dari tabel dapat dilihat bahwa kesukaan panelis terhadap aroma puree sirsak yang memilih sangat suka sebesar 43,4 \% dan suka sebanyak $20 \%$. Panelis yang memilih agak suka sebanyak 33,3\% antar suka dan tidak suka dengan sirsak. Panelis yang memilih tidak suka sebanyak 3,3\%. Persentase yang paling besar berada pada skala sangat suka, karena panelis yang mencicipi puree sirsak reta-rata suka dengan buah sirsak.

Tabel 5. Hasil Uji Hedonik Tekstur Puree Sirsak

\begin{tabular}{lcc}
\hline \multicolumn{1}{c}{ Keterangan } & $\begin{array}{c}\text { Jumlah } \\
\text { (orang) }\end{array}$ & $\begin{array}{c}\text { Percent } \\
(\%)\end{array}$ \\
\hline Sangat Tidak Suka & 0 & 0 \\
Tidak Suka & 0 & 0 \\
Agak Suka & 13 & 43,3 \\
Suka & 9 & 30 \\
Sangat Suka & 8 & 26,7 \\
\hline \multicolumn{1}{c}{ Total } & $\mathbf{3 0}$ & $\mathbf{1 0 0}$ \\
\hline
\end{tabular}

Dari tabel 5 dapat dilihat bahwa kesukaan panelis terhadap tekstur puree sirsak yang memilih agak suka sebesar $43,4 \%$. Panelis yang 
memilih suka sebanyak $30,0 \%$ dan sangat suka sebanyak 26,7\%. Panelis yang paling besar berada pada skala agak suka, karena serat dari puree sirsak tidak terlalu terasa hanya sedikit kasar.

\section{Hasil Uji Organoleptik}

Tabel 6. Hasil Uji Organoleptik Rasa Puree Sirsak

\begin{tabular}{lcc}
\hline Skala Pengukuran & $\begin{array}{c}\text { Frequency } \\
\text { (orang) }\end{array}$ & $\begin{array}{c}\text { Percent } \\
(\mathbf{\%})\end{array}$ \\
\hline Tidak Asam & 0 & 0 \\
\hline Tidak Terlalu Asam & 10 & 33,3 \\
\hline Cukup Asam & 13 & 43,3 \\
\hline Asam & 6 & 20,0 \\
\hline Sangat Asam & 1 & 3,30 \\
\hline \multicolumn{1}{c}{ Total } & $\mathbf{3 0}$ & $\mathbf{1 0 0}$ \\
\hline
\end{tabular}

Dari tabel di atas dapat dilihat bahwa panelis yang suka terhadap rasa puree sirsak yang memilih cukup asam sebesar $43,0 \%$. Panelis yang memilih asam sebanyak $20 \%$ dan sangat asam sebanyak $3,30 \%$. Panelis yang memilih tidak terlalu asam sebanyak 33,3\%. Dari tabel di atas dapat disimpulkan bahwa panelis yang memilih cukup asam untuk rasa, karena panelis masih suka dengan rasa asam dari puree sirsak. Untuk persentase yang paling besar berada pada skala cukup asam karena rasa dari puree sirsak sendiri memang dari jenis buah sirsak ratu atau sirsak manis yang rasanya tidak terlalu asam seperti sirsak biasa.

Tabel 7. Hasil Uji Organoleptik Aroma Puree Sirsak

\begin{tabular}{lcc}
\hline Skala Pengukuran & $\begin{array}{c}\text { Frequency } \\
(\mathbf{F})\end{array}$ & $\begin{array}{c}\text { Percent } \\
(\mathbf{\%})\end{array}$ \\
\hline $\begin{array}{l}\text { Tidak Beraroma } \\
\begin{array}{l}\text { Sirsak } \\
\text { Tidak Terlalu }\end{array}\end{array}$ & 0 & 0 \\
$\begin{array}{l}\text { Beraroma Sirsak } \\
\text { Cukup Beraroma }\end{array}$ & 0 & 0 \\
$\begin{array}{l}\text { Sirsak } \\
\text { Beraroma Sirsak }\end{array}$ & 12 & 40,0 \\
$\begin{array}{l}\text { Sangat Beraroma } \\
\text { Sirsak }\end{array}$ & 9 & 30,0 \\
\hline \multicolumn{1}{c}{ Total } & 9 & 30,0 \\
\hline \multicolumn{1}{c}{} \\
\hline
\end{tabular}

Dari tabel dapat dilihat bahwa panelis yang suka terhadap aroma puree sirsak yang memilih cukup beraroma sirsak sebesar $43,4 \%$. Panelis yang memilih beraroma sirsak dan sangat beraroma sirsak sebanyak 30,0 \% . Dari table di atas dapat disimpukan bahwa yang memilih cukup beraroma sirsak, karena puree sirsak ini sudah dicapur dengan air untuk aromanya tidak terlalu kuat. Persentase yang paling besar berada pada skala cukup beraroma sirsak, karena puree sirsak ini sudah tercampur dengan air sehingga aroma sirsaknya tidak terlalu kuat.

Tabel 8. Hasil Uji Organoleptik Tekstur Puree Sirsak

\begin{tabular}{lcc}
\hline \multicolumn{1}{c}{ Skala Pengukuran } & $\begin{array}{c}\text { Frequency } \\
(\mathbf{F})\end{array}$ & $\begin{array}{c}\text { Percent } \\
(\mathbf{\%})\end{array}$ \\
\hline Tidak Halus & 0 & 0 \\
\hline Tidak Terlalu Halus & 1 & 3,3 \\
\hline Cukup Halus & 20 & 66,7 \\
\hline Halus & 7 & 23,3 \\
\hline Sangat Halus & 2 & 6,7 \\
\hline \multicolumn{1}{c}{ Total } & $\mathbf{3 0}$ & $\mathbf{1 0 0}$ \\
\hline
\end{tabular}

Dari tabel dapat dilihat bahwa panelis suka terhadap tekstur puree sirsak yang memilih cukup halus sebesar 66,7\%. Panelis yang memilih halus sebanyak $23,3 \%$ dan sangat halus sebanyak 6,7\%. Panelis yang memilih tidak terlalu halus sebanyak 3,3\%. Dari table di atas dapat disimpulkan bahwa panelis yang memilih cukup halus, karena puree sirsak ini dibuat agak sedikit kasar. Presentase yang paling besar berada pada skala cukup halus, karena serat dari puree sirsak agak sedikit kasar.

Jenis kemasan yang digunakan untuk puree sirsak ada 2 seperti yang terdapat dalam Tabel 9 di bawah ini.

Tabel 9. Jenis kemasan dan gambar kemasan yang digunakan untuk puree sirsak

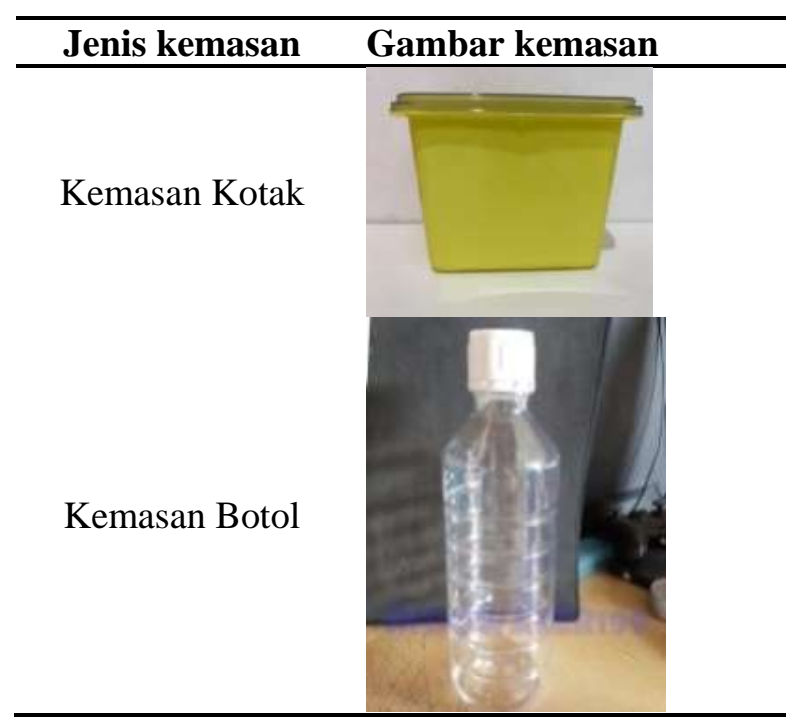


Tabel 10. Hasil Uji Kemasan Puree Sirsak

\begin{tabular}{lcc}
\hline Skala Pengukuran & $\begin{array}{c}\text { Frequency } \\
\text { (orang) }\end{array}$ & $\begin{array}{c}\text { Percent } \\
(\%)\end{array}$ \\
\hline Sangasan Kotak & & \\
Tidak Sesuai & 0 & 0 \\
Cukup Sesuai & 0 & 0 \\
Sesuai & 2 & 6,7 \\
Sangat Sesuai & 12 & 40,0 \\
\hline \multicolumn{1}{c}{ Total } & 16 & 53,3 \\
$\quad$ Kemasan Botol & $\mathbf{3 0}$ & $\mathbf{1 0 0}$ \\
Sangat Tidak Sesuai & 1 & 3,3 \\
Tidak Sesuai & 13 & 43,3 \\
Cukup Sesuai & 7 & 23,3 \\
Sesuai & 7 & 23,3 \\
Sangat Sesuai & 2 & 6,7 \\
\hline \multicolumn{1}{c}{ Total } & $\mathbf{3 0}$ & $\mathbf{1 0 0}$ \\
\hline
\end{tabular}

Dari data tabel di atas panelis paling banyak memilih sangat sesuai sebesar 53,3\%, Panelis yang memilih sesuai juga sebanyak $40 \%$. Sedangkan yang memilih cukup sesuai sebesar $6,7 \%$. Dari data table di atas dapat disimpulkan bahwa yang memilih sangat sesuai dan sesuai, karena kemasan kotak sangat mudah untuk pengemasan dan juga sangat mudah dikeluarkan apabila dalam keadaan beku. Panelis yang memilih cukup sesuai, karena melihat kemasaan botol juga baik untuk kemasan puree sirsak. Presentase yang paling besar berada pada skala sangat sesuai, karena kemasan kotak ini paling mudah untuk dikeluarkan apabila dalam keadaan beku.

Dari tabel di atas panelis yang tidak sesuai sebanyak 43,3\% dan yang memilih sangat tidak sesuai sebanyak 3,3\%. Panelis yang memilih cukup sesuai sebanyak 23,3 \%. Panelis yang memilih sesuai sebanyak $23,3 \%$ dan yang memilih sangat sesuai sebanyak 6,7 \%. Sehingga dapat disimpulkan bahwa, Panelis yang memilih tidak sesuai dan sangat tidak sesuai karena mereka lebih cocok dengan kemasan kotak. Panelis yang memilih cukup sesuai karena mereka suka dengan kedua kemasan baik kotak maupun botol. Panelis yang memilih sesuai dan sangat sesuai, karena mereka lebih suka dengan kemasan botol dibandingkan kotak. Persentase yang paling besar pada skala tidak sesuai, karena kemasan kotak lebih mudah pengemasan dan pengeluarannya apabila produknya dalam keadaan beku.

\section{Logo, Nama, Warna dan Slogan}

Logo berbentuk lonjong untuk mewakili produk yang akan dijual, yang dimana gambar bulat lonjong terinspirasi dari bentuk buah sirsak yang bulat memanjang. Nama Sirsi Fruit diambil dari singkatan buah sirsak, agar para konsumen lebih cepat mengenal produk puree tersebut. Warna dasar hijau dari logo Sirsi Fruit mewakili buah - buahan sirsak yang segar alami. Warna putih dari tulisan Sirsi Fruit mewakili daging buah sirsak yang berwarna putih. Slogan "Fresh and Healty" dibuat untuk mewakili dimana puree sirsak ini berasal dari buah-buahan segar dan juga sangat bermanfaat untuk kesehatan tubuh.

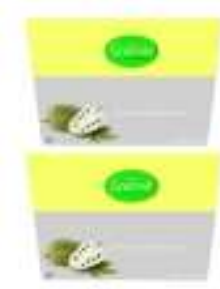

Gambar 2. Logo

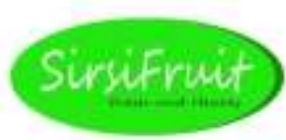

Gambar 3. Nama

Puree sirsak memiliki kandungan antioksidan yang sangat banyak salah satunya adalah Vitamin C yang terdapat pada puree sirsak sebersar $0,13 \mathrm{mg}$ per 100 gr. Antioksidan ini dapat mencegah berbagai macam penyakit seperti asam urat, kolesterol, darah tinggi. Kandungan gizi puree sirsak tersebut ikut ditampilkan dalam kemasan.

\section{Analisis Kandungan Gizi}

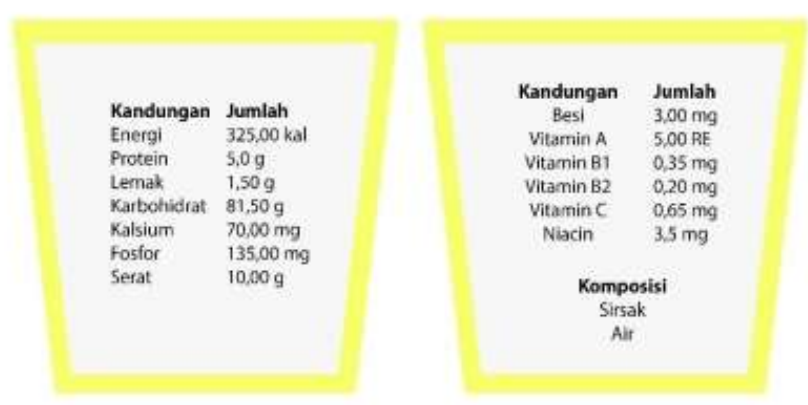

Gambar 4. Tabel Kandungan Gizi puree sirsak pada kemasan 


\section{Harga Pokok Penjualan (HPP)}

Tabel 11. Varibel Cost Puree Sirsak : 3 CUP @ 1

\begin{tabular}{|c|c|c|c|}
\hline $\begin{array}{c}\text { Nama } \\
\text { Produk }\end{array}$ & Ukuran & Harga & $\begin{array}{c}\text { Harga } 3 \\
\text { Cup }\end{array}$ \\
\hline $\begin{array}{l}\text { Buah } \\
\text { Sirsak }\end{array}$ & $4 \mathrm{KG}$ & Rp. 60.000 & $\begin{array}{l}\text { Rp. } \\
60.000\end{array}$ \\
\hline Air Aqua & $19 \mathrm{LT}$ & Rp. 17.000 & Rp. 1.500 \\
\hline Kemasan & $3 \mathrm{PCS}$ & Rp. 19.500 & $\begin{array}{l}\text { Rp. } \\
19.500\end{array}$ \\
\hline Stiker & $3 \mathrm{PCS}$ & Rp. 16.500 & $\begin{array}{l}\text { Rp. } \\
16.500\end{array}$ \\
\hline TOTAL & & $\begin{array}{l}\text { Rp. } 97.500 \\
\text { / } 3 \text { CUP }\end{array}$ & $\begin{array}{l}\text { Rp. } \\
97.500 \\
\text { Rp. } \\
\text { 32.500 / } \\
\text { CUP }\end{array}$ \\
\hline
\end{tabular}

\section{Fix Cost}

Gaji Karyawan :

1 orang x @ Rp, 600.000,- x 12 bulan=Rp.

7.200 .000

Biaya Listrik dan Air :

1 x @ Rp. 300.000 x 12 bulan=Rp. 3.600 .000

Total $=$ Rp. 10.800 .000

Biaya tetap untuk gaji karyawan, biaya listrik dan air adalah biaya tetap operasional yang akan di tambahkan dengan variable cost untuk menghitung HPP.

\section{Harga Pokok Penjualan}

Dalam sehari, Sirsi Fruit mampu menghasilkan 50 Cup dengan ukuran kotak 1 liter. Biaya yang diperlukan untuk 1 cup puree sirsak Rp. $32.500,-$, Sirsi Fruit menargetkan penjualan 1500 cup dalam sebulan, 18.000 cup dalam setahun.

Unit Cost : Variabel Cost + (Fixed Cost / Target Sales)

$: 32.500+(10.800 .000 / 1800)$

$: 32.500+6000$

$: 38.500$

Price : Unit Cost / ( 1 - Desired Return on

Sales)

: $38.500 /(1-0,5)$

$: 77.000$

Harga diatas adalah harga jual untuk puree sirsak per cup sebesar Rp. 77.000 nett.

\section{Pemasaran STP (Segmenting, Targeting dan Positioning)}

Segmenting : Puree sirsak ini di buat untuk pastry shop, agar lebih mudah dan praktis untuk produksi.

Targeting : Puree sirsak ini dikemas dalam ukuran 1 liter, karena konsumen yang dituju adalah pastry shop yang memproduksi berbagai macam mousse dan pudding.

Positioning : Positioning puree sirsak ini di pasaran harganya berada di bawah puree yang ada dipasaran. Karena puree dipasaran kebanyakan di import dari luar negeri dan harganya juga cukup mahal. Untuk puree sirsak ini bahan baku dari dalam negeri, sehingga harga jual di pasaran berkisar Rp. 77.000. Puree sirsak buatan dalam negeri ini, harganya dapat lebih bersaing dengan puree yang ada di pasaran.

Tabel 12. Daftar Harga Produk Puree Yang Ada Dipasaran

\begin{tabular}{|c|c|c|c|}
\hline Merek Import & Harga & $\begin{array}{c}\text { Selisih } \\
\text { Harga } \\
\text { Dengan } \\
\text { Sirsi Fruit }\end{array}$ & $\begin{array}{c}\text { Selisih } \\
\text { Percent } \\
\text { Harga } \\
\text { Dengan } \\
\text { Sirsi } \\
\text { Fruit }\end{array}$ \\
\hline RaviFruit Puree & $\begin{array}{c}\text { Rp. } \\
\text { R2 }\end{array}$ & Rp. 75.000 & $97,4 \%$ \\
\hline $\begin{array}{l}\text { Boiron Puree } 1 \\
\mathrm{~L}\end{array}$ & $\begin{array}{c}\text { Rp. } \\
215.000\end{array}$ & Rp. 138.000 & $179,2 \%$ \\
\hline $\begin{array}{l}\text { Fruit Rouges } \\
\text { Puree 1 L }\end{array}$ & $\begin{array}{c}\text { Rp. } \\
187.000\end{array}$ & Rp. 110.000 & $142,9 \%$ \\
\hline $\begin{array}{ll}\text { Denali } & \text { Fruit } \\
\text { Puree 2 L } & \end{array}$ & $\begin{array}{c}\text { Rp. } \\
235.000\end{array}$ & Rp. 158.000 & $205,2 \%$ \\
\hline \multicolumn{4}{|l|}{ Merek Lokal } \\
\hline Jardin Puree $1 \mathrm{~L}$ & $\begin{array}{c}\text { Rp. } \\
135.000\end{array}$ & Rp. 58.000 & $75,3 \%$ \\
\hline Genova $1 \mathrm{~L}$ & $\begin{array}{c}\text { Rp. } \\
105.000\end{array}$ & Rp. 28.000 & $36,4 \%$ \\
\hline $\begin{array}{l}\text { Sirsi } \\
\text { Puree }\end{array}$ & $\begin{array}{c}\text { Rp. } \\
77.000\end{array}$ & & \\
\hline
\end{tabular}

Dari tabel di atas diketahui bahan puree import lebih mahal dibandingkan puree produksi dalam negeri. Lebih baik memproduksi buahbuah lokal agar harga jual dapat bersaing dan dapat di eksport ke luar negeri. 
Marketing Mix 4P (Product, Price, Place, Promotion)

Product

Produk Sirsi Fruit adalah poduk yang dibuat dari buah-buah lokal dalam negeri, dimana puree sirsak ini banyak manfaatnya untuk kesehatan. Puree sirsak selain baik untuk kesehatan, dapat juga dibuat penjadi pastry product. Puree sirsak ini dibuat agar dapat bersaing dengan puree yang ada dipasaran.

Price

Produk akan dijual seharga $\mathrm{Rp}, 77.000$,untuk setiap 1 Liter. Nilai ini telah di pertimbangkan dengan menghitung harga pokok penjualan. Harga saat ini juga sesuai dengan daya beli pelanggan, dan harga produk kompetitior yang ada di pasaran.

Place

Distribusi produk akan diperoleh terutama melalui empat cara berbeda. Pertama, produk dapat di beli secara langsung di tempat produksi. Kedua, produk tersebut dapat dibeli melalui telepon dan akan dikirim langsung ke pembeli. Ketiga, akan bisa di dapatkan melalui event saat Sirsi Fruit mengikuti pameran. Keempat, dapat di beli melalui aplikasi online yang akan dengan mudahnya dapat mengambil produk dan mengirimkannya secara langsung. Contohnya Gojek atau Grab.

\section{Promotion}

Promosi produk Sirsi Fuit akan di lakukan oleh media sosial dan pemasaran langsung. Pasaran media sosial seperti Instagram, Tokopedia, Shopee dan Bukalapak akan digunakan. Pemasaran langsung, seperti brosur, mulut ke mulut, dan event bazar, juga dilakukan ketika waktunya tepat.

\section{Kesimpulan}

Puree sirsak sangat banyak manfaat dan sangat baik untuk tubuh, karena antioksidan dalam buah sirsak sangat tinggi. Untuk mengetahui kandungan gizi dalam puree sirsak maka dilakukan uji lab untuk mengetahui kadar vitamin $\mathrm{C}$ yang ada di dalam puree sirsak, yang terbukti tinggi dengan nilai $0,13 \mathrm{mg} / 100 \mathrm{gr}$. Puree sirsak akan di kemas menggunakan kemasan kotak, yang ramah lingkungan dan dapat di daur ulang, bukan untuk konsumsi Individu. Puree sirsak ini akan di pasarkan ke Pastry shop, Café, dan Restaurant. Penelitian ini berfokus pada suplai Pastry shop.

\section{Daftar Pustaka}

Ashari, S. (2006). Meningkatkan Keunggulan Bebuahan Tropis Indonesia. Penerbit Andi, Yogyakarta.

Broto, W. (2003). Mangga: Budidaya, Pascapanen, dan Tata Niaganya. Agro Media Pustaka. Jakarta.

Daryanto. (2011). Manajemen Pemasaran: Sari Kuliah. Bandung: Satu Nusa.

Kotler dan Keller. (2008). Manajemen Pamasaran. Erlangga: Jakarta.

Kotler, Philip dan Armstrong, Gray. (2001). Prinsip-prinsip Pemsaran (Principles Of Marketing) , Edisi Bahasa Indonesia, Jilid 1. Jakarta : Penerbit Erlangga.

Maria. (2013). Kandungan Nutrisi dan Manfaat Buah Sirsak Untuk Kesehatan.

Setyadjit, Widaningrum dan Sulusi P, (2005). Agroindustri puree mangga : Mengatasi panen berlimpah. Warta Penelitian dan Pengembangan Pertanian 27(5):4-5.

Teyler, Leslie. (2002). Herbal Secrets of The Rainforest.

Tjiptono, Fandy dan Gregorius Chandra. (2012). Pemasaran Strategik. ANDI : Yogyakarta.

Umme A, Asbi B.A, Salmah Y, Junainah A.W, Jamilah B. 1997. Characteristics of Soursop Natural Puree and Determination of Optimum Conditions for Pasteurization. J.Food Chemistry 58: 1 19-1 24.

Wijayanti, Titik. (2012) Management Marketing Plan, PT Elex media Komputindo, Jakarta. 